https://dx.doi.org/10.4314/gjas.v54i1.1

\title{
Evaluation of efficacy of false yam (Icacina oliviformis) as surface protectant against rot pathogens of white yam (Dioscora rotundata Poir)
}

\author{
E. N. K. SOWLEY, F. KANKAM* \& R. M. NSARKO \\ (E.N.K.S; F.K \& R.M.N.: Department of Agronomy, Faculty of Agriculture, University for Devel- \\ opment Studies, P. O. Box TL 1882, Nyankpala, Ghana) \\ *Corresponding author's email: fkankam@uds.edu.gh
}

\begin{abstract}
Rots in yam tubers are the dominant cause of postharvest losses. Therefore, studies were conducted to identify the rot-causing organisms in yam and to evaluate the efficacy of false yam (Icacina oliviformis) plant extracts as surface protectants in the storage of yam. The experiment was laid out in a completely randomized design (CRD) design with five treatments (fruit, root and leaf extract of false yam, Mancozeb and tap water) replicated three times. Two concentrations $(50 \%$ and $100 \%)$ of each extract were also tested. Species were identified based on the structural features, the characteristics and properties of the spore and mycelium. A spore suspension of yam rot fungi was sprayed on healthy yam tubers that had been pretreated with the extracts. Results showed that fungi isolated from rotted yams were Aspergillus niger, A. flavus and Penicillium sclerotigenum. Leaf extracts (both 50\% and 100\%) had the highest growth inhibitions on all the three fungi isolated in vitro. Tubers treated with root and leaf extracts of false yam had a decreased tuber rot lengths of $1.80 \mathrm{~mm}^{2}$ and $2.17 \mathrm{~mm}^{2}$, respectively. The leaves and roots of false yam can be used as a surface protectant of yam in place of Mancozeb.
\end{abstract}

Keywords: Icacina oliviformis; Dioscora rotundata; Mancozeb; Pathogenicity; Aspergillus spp. Original scientific paper. Received 22 Nov 2018; revised 26 Jun 2019

\section{Introduction}

Yam (Dioscorea spp.) is one of the most important dietary sources of energy and a basic foodstuff in the tropical and humid regions of Africa, South America, India and South-East Asia (Achi, 2000; Adegbite et al., 2006; Babajide et al., 2007; Oluwole et al., 2013). There are many varieties of yam species but white yam (Dioscorea rotundata) and water yam (Dioscorea alata) are the widely grown species in Ghana (Aboagye et al., 2015) and thus are economically important species. Ghana produces $25 \%$ of yam transacted on the global market (SRID, 2011) and ranks third after Nigeria and Ivory Coast and contributes $17 \%$ of Agricultural Gross Domestic Product (AGDP) (FAO, 2009). Yam is also considered the food of choice on many occasions and festivals. It is an indispensable part of the bride price in the Northern Regions of Ghana and part of Nigeria (Hahn et al., 1987). It has become a source of foreign exchange for some countries in the yam

Ghana Jnl Agric. Sci. 54 (1), 1 - 9

GJAS is an Open Access Journal and distributed under the terms of the Creative Commons (CC) License [CC BY 4.0] 
belt. Thus the economic importance of yam and its role in ensuring food security in Ghana cannot be overemphasized.

Yam production and marketing is faced with several problems. Diseases contribute greatly to high yield losses on the field and in storage. Yam plants are very susceptible to fungi, bacterial and viral infections on the field and in storage which result in the incidence of rots. Rots in yam tubers are the dominant cause of postharvest losses among other factors (Aidoo, 2007). About $60 \%$ of white yam varieties get rotten when stored for less than six months in Nigeria (Adesiyan \& Odihirin, 1975). Most rots of yam tubers are caused by pathogenic fungi such as Aspergillus flavus, A. niger, Botryodiplodia theobromae, Fusarium oxysporum, $F$. solani, Penicillium chrysogenum, P. oxalicum, Rhizoctonia spp. and Rhizopus nodosus (Okigbo, 2004; Aidoo, 2007; Asare- Bediako et al., 2007).

Synthetic chemicals such as sodium orthiophenylphenate, borax, captan, thiobendazole, benomyl, bleach (sodium hypochlorite) have been found to significantly reduce storage rots in yam (Noon, 1978). Other control methods involve the use of microorganism such as Trichoderma viride and Bacillus subtilis (Okigbo \& Ikediugwu, 2000). However, the financial cost involved in applying these methods and the dangers associated with chemical usage has limited farmers adopting these innovations in developing economies such as Ghana. The lack of expertise in the safe handling of chemicals among most farmers is another challenge. There is therefore the need to discover environmentally and economically friendly control methods to help address the problems of farmers and consumers. The use of botanical extracts has been reported to be very effective in controlling diseases due to the anti-bacterial and anti-fungal properties they possess. Botanicals are locally available (cheap), have little or no toxicity and have simple preparation procedures. There are several local plant species whose extracts have proved effective in protecting yam produce before and after harvest. Neem plant (Azadiractha indica), black pepper (Piper nigrum), ginger plant (Zingiber officinale), Jatropha curcas, false yam (Icacuna oliviformis) are examples of numerous plants that can be used as surface protectants on yam tuber (Amusa et al., 2003; Saetae \& Suntornsuk, 2010; Sowley et al., 2013). Some yam species such as $D$. piscatorum have toxic properties that allow them to be used in the production of insecticides. An insecticide from D. piscatorum is used in controlling insect pests of rice in Malaysia (Ooi \& Shepard, 1994). Extracts from $D$. deltoidea is used in the production of anti-lice shampoo in India (Coursey, 1967). False yam contains bitter toxic compounds, Icacinon and Icacinols which prevent pests and diseases causing organisms from feeding. As a result of these properties, the plant has not been a host to pests and diseases causing organisms (Vanhaelen et al., 1987). The plant usually grows in the wild and is seldom cultivated. False yam has several uses. The efficacy of Icacina senegalensis leaf and tuber extracts for the management of sweet potato beetle $(C y$ las spp.) and cowpea aphids (Aphis cracivora) have been reported (Alale et al., 2017).

False yam is readily available in the Northern parts of Ghana. Therefore, the objectives of this study were to isolate and identify the pathogens associated with rots of stored white yam tubers and evaluate the efficacy of false yam extracts as surface protectants in stored white yam tubers in vitro and in vivo. 


\section{Materials and methods}

Study site

The in vitro experiment was conducted at the Spanish Laboratory of the University for Development Studies, Nyankpala campus. The area experiences a unimodal rainfall pattern with $1022 \mathrm{~mm}$ being an annual average. The in vivo experiment was conducted in a modern yam barn located at the 'Farming for The Future' of the University for Development Studies, Nyankpala campus. The campus is situated at latitude $9^{\circ} 25^{\prime} 41^{\prime \prime} \mathrm{N}$ and longitude $0^{\circ} 58$ '42' $\mathrm{W}$ and $200 \mathrm{~m}$ above sea level.

\section{Experimental design}

The experiment was laid out in a completely randomized design (CRD) design with five treatments (involving three extracts and two controls) replicated three times.

\section{Isolation and identification of fungal patho- gens from rotten yam tuber}

The rotten tubers collected from the Tamale central market were washed under running tap water and allowed to dry under laboratory conditions. Pieces of diseased tissues cut from the periphery of rotten yam tubers with a sterilized knife were rinsed in sterilized water, surface sterilized with $70 \%$ ethanol. Three pieces ( $3 \mathrm{~mm}$ diameter) of the infected tissues were picked with flamed sterilized forceps and dried in a sterile Lamina flow chamber. The dried disease tissues were plated on the solidified Potato Dextrose Agar (PDA) supplemented with streptomycin sulfate (PDA: 200 g potato, $20 \mathrm{~g}$ sucrose, $18 \mathrm{~g}$ agar, $0 \cdot 125 \mathrm{~g}$ streptomycin sulphate $\mathrm{L}^{-1}$ and 1,000 $\mathrm{ml}$ distilled water, $\mathrm{pH}$ 7.0) in Petri dishes. The inoculated plates were incubated at room temperature $\left(28^{\circ} \mathrm{C}\right)$ and observations were made daily for the emergence of colonies. Mycelia that emerged from the plated yam tissues were sub-cultured onto fresh PDA. Species were identified based on the structural features, the characteristics and properties of the spore and mycelium when studied under the compound microscope. These morphological characteristics were used in identifying the fungal organisms to the species level, as described by Barnett and Hunter (1998). Cultural characteristics such as conidial masses, colony growth and colour were observed on PDA at $26 \pm 2^{\circ} \mathrm{C}$; 10 replicates were prepared for each isolate. The mean colony growth for each isolate from 48 to 168 hours (i.e. $2-7$ days) was calculated. The colour of each colony and conidial masses were also recorded on the seventh day. The description and naming of the Colletotrichum species were done according to Chaube and Pundhir (2005); IMI (1995); Barnett and Hunter (1998).

\section{Pathogenicity test}

The inocula used for the pathogenicity tests were obtained from the different fungal species. Healthy white yam tubers were washed with tap water and distilled water and thereafter sterilized with $70 \%$ ethanol. Cylindrical discs ( $1 \mathrm{~cm}$ thick) were removed from the tuber with a five-millimeter diameter cork borer (sterilized by dipping in alcohol followed by flaming). The sterile cork borer was used to cut plugs from the one-week-old cultures of the fungal isolates to be tested. These fungal plugs ware then placed in the holes created in the yam tubers after which the removed yam tuber discs ware used to plug the holes. Candle wax was applied at the point of inoculation to seal the edges of the replaced yam discs. This was done for all the three species (A. niger, $A$, flavus and Penicillium sclerotigenum) obtained in pure cultures. A control was set up in which the sterile cork borer was used to remove a disc 
of the tuber tissue. The tuber disc was used to plug the hole and its edges sealed with candle wax. In the control, no fungal organism was placed in the hole. The tubers were incubated for seven days at $28^{\circ} \mathrm{C}$. These activities were carried out inside a sterile environment (Aidoo, 2007).

\section{Preparation of plant extracts and Mancozeb}

The method of Okigbo and Ogbonnaya (2006) was used in the preparation of the plant extracts with some modifications. Fresh fruits, leaves and roots of false yam were washed thoroughly under running tap water. The fruits and the roots were cut into small chunks separately. The plant parts were further homogenized into a paste separately with a blender for five minutes. A cold water extract of the ground fruits, leaves and roots were separately prepared by adding $50 \mathrm{~g}$ of each plant extract to $100 \mathrm{ml}$ of cold sterile water in a $500 \mathrm{ml}$ beaker. It was vigorously stirred and allowed 1 hour for settling, and then filtered through folds of sterile cheesecloth (Okigbo \& Ogbonnaya, 2006) to obtain a stock solution (100\%). Fifty percent (50\%) concentration of each plant part extract was prepared from the stock. Two concentrations $(50 \%, 100 \%)$ of each extract were used as treatments. The efficacy of each of the extracts was tested for their fungicidal activity against yam tuber rot fungi.

Mancozeb WP was prepared by adding $10 \mathrm{~g}$ of Mancozeb WP to $100 \mathrm{ml}$ of distilled water. The mixture was stirred thoroughly and used as a positive control. Tap water was also used as a negative control.

Effect of the plant extract in vitro on growth of yam rot fungi

The method of Amadioha and Obi (1999) was used to determine the effect of the extracts on fungal growth. This involved creating four equal sections on each Petri dish by drawing two perpendicular lines at the bottom of the Petri dish, the point of intersection indicating the center of the plate. This was done before dispensing PDA into each of the plates. Four milliliters $(4 \mathrm{ml})$ from each of the two concentrations $(50 \%, 100 \%)$ of each extract was dispensed into $9 \mathrm{~cm}$ diameter Petri dishes after which $20 \mathrm{ml}$ of melted PDA was added, mixed gently and allowed to solidify (Okigbo \& Ogbonnaya, 2006). A disc (5 $\mathrm{mm}$ diameter) of the pure culture of the isolates were placed on the plate, just at the point of intersection of the two lines drawn at the bottom of the Petri dish and incubated at room temperature. Control experiments were set up without the addition of any plant extract. Positive control was set up by adding a broad spectrum fungicide (Mancozeb) that has been established to control rot fungi. Treatments were replicated three times.

Measurement of growth as diameter of a growing fungal colony was undertaken at intervals of twenty-four hours using a ruler. Fungitoxicity was recorded in terms of percentage colony inhibition by the extracts and calculated according to the formula of Amadioha \& Obi (1999). \% Growth inhibition $=[(\mathrm{DC}-\mathrm{DT}) / \mathrm{DC}]$ X 100 Where DC = average diameter of control, and DT $=$ average diameter of fungal colony with treatment.

\section{Activity of extracts in vivo}

\section{Storage design}

A modern barn made of concrete floor with a cement wall about 30 inches high and woods nailed together increased the wall to about 7 feet high. The barn was roofed with aluminum sheets and wire mesh was used to seal the ventilation windows to prevent rodent attack. The 
experiment was laid in a randomized complete block design (RCBD) with five treatments (fruit, root and leaf extract of false yam, Mancozeb and tap water) replicated three times.

30 healthy tubers of one cultivar (Nyumanle) of white yam were used in the storage experiment. Each shelf contained ten tubers. Two tubers in each shelf belonged to one treatment. Two tubers in each shelve were dipped into each of the treatments separately for $50 \mathrm{sec}-$ onds prior to storage. Treated tubers were adequately labeled in each shelf.

\section{Inoculum application}

A spore suspension of yam tuber rot fungi was prepared by adding $4 \mathrm{ml}$ of water to a plate containing sporulated fungi. The mycelia were scraped off and the mixture filtered through a cotton cloth. To get all the mycelia, the procedure was repeated for the same plate. This was done for 10 plates. Okigbo \& Ogbonnaya, (2006) method of inoculation was used with some modification. The treated tubers were airdried for 24 hours before spore suspension of $6 \times 10^{4}$ spores per $\mathrm{ml}$ of distilled water of each pathogen was sprayed on them using a spray gun. All the treated tubers were incubated under polyethylene sheets in the barn for 15 days. This was done to obtain optimum humidity conducive for spore germination and mycelia growth.

Effectiveness of extracts as surface protectants of yam tubers against rot pathogens

After 15 days, the spore had germinated and grown considerably into the yam tissues through the natural openings on the yam. The tubers were bisected and the area of rot for each tuber was measured by multiplying the length of rot by the breath of rot. Measurements of tu- bers treated alike were calculated and an average was found.

\section{Data analysis}

Data collected were subjected to one-way Analysis of Variance (ANOVA) with Genstat ( $18^{\text {th }}$ edition). The least significant difference (LSD) test was used to separate the treatment means at 5\% significance level. Data on means area of rot yam were subjected to $\log _{10}(\mathrm{x}+1)$ transformation.

\section{Results}

Occurrence of fungal isolate from rotten yam Three fungal species were isolated from the rotten yam tubers. These were Aspergillus niger, A. flavus and Penicillium sclerotigenum and their percentage occurrences were $48 \%$, $19 \%$ and $33 \%$ respectively (Table 1 ).

TABLE 1

Occurrence of Fungal isolate from rotten yam.

\begin{tabular}{lcc}
\hline Isolates & Frequency & $\begin{array}{c}\text { Percentage } \\
(\%)\end{array}$ \\
\hline $\begin{array}{l}\text { Aspergillus niger } \\
\text { Penicillium } \\
\text { Sclerotigenum }\end{array}$ & 26 & 48 \\
$\begin{array}{l}\text { Aspergillus } \\
\text { flavus }\end{array}$ & 18 & 33 \\
\hline Total & 10 & 19 \\
\hline
\end{tabular}

Effects of extracts on growth of rot fungi in vitro Leaves extract (50\% and 100\%) had the highest growth inhibition in all isolates. At $100 \%$ leaf concentration, growth inhibition on A. flavus was $61.63 \%, A$. niger was $65.8 \%$ and P. sclerotigenum was $64.4 \%$ compared to $50 \%$ leaf concentration where growth inhibition on $A$. flavus was $54.66 \%$, A. niger was $59.1 \%$ and $P$. sclerotigenum was $60.0 \%$. The root extracts at $100 \%$ had higher growth inhibition 
than at $50 \%$. Growth inhibition at $50 \%$ root extract were A. flavus, $45.78 \%$, A. niger, $51.7 \%$ and $P$. sclerotigenum, $55.3 \%$ while at $100 \%$ root extract, growth inhibition on $A$. flavus was $55.09 \%$, A. niger was $58.0 \%$ and $P$. sclerotigenum was $58.7 \%$. Growth inhibition on $P$. sclerotigenum by fruit extract at $50 \%$ was $42.1 \%$ and at $100 \%, 52.4 \%$. Growth inhibition on A. flavus by fruit extract at $50 \%$ was $54.49 \%$ and at $100 \%, 50.25 \%$. The fruit extract of the false yam against $A$. niger had the lowest growth inhibition with $3.2 \%$ at $50 \%$ fruit extract and $0.4 \%$ at $100 \%$ fruit extract (Table 2). Mancozeb had $100 \%$ growth inhibition on all the fungi.

TABLE 2

Effects of extracts on growth of rot fungi in vitro

\begin{tabular}{|c|c|c|c|c|c|c|}
\hline \multirow[t]{3}{*}{ Treatments } & \multicolumn{6}{|c|}{ \% Growth Inhibition } \\
\hline & \multicolumn{2}{|c|}{ A. flavus } & \multicolumn{2}{|c|}{ A. niger } & \multicolumn{2}{|c|}{ Penicillium sp. } \\
\hline & $50 \%$ & $100 \%$ & $50 \%$ & $100 \%$ & $50 \%$ & $100 \%$ \\
\hline Fruit extracts & 54.50 & 50.20 & 3.20 & 0.40 & 42.10 & 52.40 \\
\hline Root extracts & 45.80 & 55.10 & 51.70 & 58.00 & 55.30 & 58.70 \\
\hline Leaf extracts & 54.70 & 61.60 & 59.10 & 65.80 & 60.00 & 64.40 \\
\hline Mancozeb & 100.0 & 100.0 & 100.0 & 100.0 & 100.0 & 100.0 \\
\hline Tap water & 0.00 & 0.00 & 0.00 & 0.00 & 0.00 & 0.00 \\
\hline $\operatorname{LSD}(0.05)$ & 6.45 & 7.41 & 5.91 & 3.97 & 3.89 & 5.31 \\
\hline $\mathrm{CV}(\%)$ & 2.40 & 2.00 & 1.90 & 3.00 & 3.60 & 4.50 \\
\hline
\end{tabular}

Effects of extracts as surface protectants of yam tubers against rot pathogens

The effect of plant extracts of false yam on tuber rot length of white yam is shown in Table 3. The mean tuber rot length varied significantly between tubers treated with each extract $(P<$ $0.05)$. Plants treated with root and leaf extracts had significantly fewer tuber rot compared to control plants treated without these plant extracts.
TABLE 3

Effects of treatments as surface protectants of yam tubers against rot pathogens

\begin{tabular}{lcc}
\hline \multirow{2}{*}{ Treatment } & \multicolumn{2}{|c}{ Means of area of rot $\mathrm{t}^{a}\left(\mathrm{~mm}^{2}\right)}$. \\
\cline { 2 - 3 } & $\begin{array}{l}\text { Untrans- } \\
\text { formed mean }\end{array}$ & $\begin{array}{l}\text { Transformed } \\
\text { mean }\end{array}$ \\
\hline Fruit extract & 2119.00 & 3.33 \\
Root extract & 63.00 & 1.80 \\
Leaf extract & 147.00 & 2.17 \\
Mancozeb & 94.00 & 1.97 \\
Tap water & 3350 & 3.53 \\
(Control) & 168.90 & 0.28 \\
LSD (0.5) & 7.80 & 1.80 \\
CV (\%) & \\
\hline
\end{tabular}

a: $\log _{10}(\mathrm{x}+1)$ transformed, where $\mathrm{x}=$ area of rot yam 


\section{Discussion}

Three fungi namely Aspergillus niger, A. flavus and Penicillium sclerotigenum were isolated from the rotten yam tubers. The pathogenicity test revealed that A. niger, A. flavus and Penicillium sclerotigenum caused rot and confirm reports by other studies that these fungi are associated with rot in yam tubers by a number of workers (Ogundana et al., 1970; Ikotun, 1989; IITA, 1993; Okigbo, 2004; Asare-Bediako et al., 2007). The tubers inoculated with Penicillium sclerotigenum turned brown, hard and dry. A. niger-inoculated tubers turned brown with yellowish margin. This agrees with IITA (1993)'s report that Penicillium spp. and A. niger causes dry rot of yam. Tubers inoculated with A. flavus turned brown and soft. This also agrees with Ikotun (1989) who reported that tubers infected by soft rot organisms often turned brown, soft and became wet due to rapid collapse of cell walls of tissues.

There was $100 \%$ growth inhibition by Mancozeb on all the fungi studied. Harlapur et al. (2007) also reported that Mancozeb was found to be most effective in inhibiting the mycelial growth of Exserohilum turcicum. The leaf extracts at $100 \%$ concentrations had the highest growth inhibition followed by the root extracts, then the fruit extracts at the same concentrations. This implies that there were probably higher concentrations of some antifungal active ingredients in the leaves followed by the roots with the fruit having the least concentration.

False yam fruits extracts poorly inhibited the mycelia growth of $A$. niger as opposed to the high efficacy of the leaf and the root extracts of the plant on the fungi. This could be due to the presence of these same antifungal active ingredients in the leaf and root extracts which may be limited or absent in the false yam fruit extract. False yam contains Icacinon and Icacinol compounds (Alale et al., 2017) which are responsible for its fungal toxicity.

A general increase in growth inhibition of fungal activity as the concentration of the root and leaf extracts increased from 50\% to $100 \%$ confirms conclusions by Kalimuthu et al. (2013) that the inhibitory activity of plant extract is largely dependent on the concentration, part of the plant used and the microbes tested.

Results obtained from the application of extracts on yam tubers indicate that the fruit extract could not protect the yam tubers against rot-causing organisms. In most cases, microorganisms gain access into yams through natural opening and wounds that occur during harvesting and transportation from field to storage barns (Ogundana et al., 1970). The spore suspension that was directly inoculated on the yam tubers in storage may have gained access into the tubers through the natural openings. Since most of the tubers treated with Mancoz$\mathrm{eb}$, root and leaf extracts had a decreased tuber rot lengths, it is likely that they inhibited spore germinating on the yam tubers.

False yam leaf and root extract can be substituted for Mancozeb since they all inhibited spores from germinating into yam tubers. False yam fruit extract was not an effective surface protectant possibly due to the low concentrations or absence of Icacinon and Icacinol compounds in them.

\section{Conclusion}

The study revealed that Aspergillus niger, A. flavus and Penicillium sclerotigenum are pathogenic in yam and cause yam rot. Leaves and roots of false yam can be used as a surface protectant of yam as a cheaper and more environmentally friendly option to Mancozeb. 
However, fruits extract of false yam is not toxic to some strain of fungi (A. niger). The effectiveness of a botanical extract in controlling fungi depends on the part of the plant used as well as the concentration of the plant extract used.

\section{Acknowledgement}

The authors are thankful to the Laboratory Technicians and Research Assistants of the Agronomy Department of the University for Development, for assisting in the data collection.

\section{REFERENCES}

Aboagye, L. M., Nyadanu, D., Opoku-Agyeman, M. O., Owusu, S. K. \& Asiedu-Darko, E. (2015) Survey of diversity and production of yams in four communities in Southern Ghana. African Journal of Agriculture Research 10(24), $2453-2459$.

Achi, O. K. \& Akubor, P. I. (2000). Microbiological characterization of yam fermentation for Elubo (yam flour) production. World Journal of Microbiology and Biotechnology 16(37), $1-7$.

Adegbite, A., Saka, J., Agbaje, G., Owolade, G., Olaifa, O. \& Lawa, A. (2006) Survey of plant-parasitic nematodes associated with yams in Edo, Ekiti and Oyo states of Nigeria. African Journal of Agriculture Research 1(4), 125 - 130.

Adesiyan, S. O. \& Odihirin, R. A. (1975) Histopathology studies of the yam tuber (Dioscorea rotundata Poir) infected with Scutellonena bradys (Steiner \& Hettew). International Biodeterioration Bulletin 11, 48 - 55.

Aidoo, K. A. (2007) Identification of yam tuber rot fungi from storage systems at the Kumasi Central market. A dissertation submitted to Faculty of Agriculture, Kwame Nkrumah
University of Science and Technology, Kumasi, Ghana. $1-23$.

Amadioha, A. C. \& Obi, V. I. (1999) Control of anthracnose disease of cowpea by Cymbopogon oitratus and Ocimum gratissimum. Acta. Phytopathologia et Entomological Hungarica 34(1-2), $83-89$.

Alale, T. Y., Opoku, N. \& Adarkwah, C. (2017) The efficacy of aqueous false yam (Icacina oliviformis) tuber extract against cowpea aphids (Aphis cracivora Koch). Journal of Young Investigators 32(4), $22-24$.

Amusa, N. A., Adegbite, A. A., Muhammed, S. \& Baiyewu, R. A. (2003) Yam diseases and its management in Nigeria. Africa Journal of Biotechnology 2(12), 497 - 502.

Asare-Bediako, E., Suwemimo, F. A. \& Opoku-Asiama, Y. (2007) Microorganisms associated with rot of minisetts of white yam (Dioscorea rotundata Poir). Research Journal of Microbiology 2(3), 278 - 283.

Babajide, J. M., Babajide, S. O. \& Oyewole, O. B. (2007) Survey of traditional dry-yam slices (Gbodo) processing operations in Southwest, Nigeria. American-Eurasian Journal of Sustainable Agriculture 1(1), 45 - 49.

Barnett, H. L. \& Hunter B. B. (1998) Illustrated Genera of Imperfect Fungi, 4th ed. Burges Publications Company, Minnesota, UK.

Chaube, H. \& Pundhir, V. S. (2005) Crop Diseases and their Management. Prentice Hall of India, New Delhi. 132 - 245.

Coursey, D. G. (1967) Yam storage. A review of storage practices and information on storage losses. Journal of Stored Products Research 38, $841-852$.

FAO. (2009) FAOSTAT. Statistics Division of the Food and Agricultural Organization. 
Hahn, S. K. \& Osiru, D. S. O. (1987) Yam production and future prospects, outlook on Agriculture, U. T. A, Nigeria. 16, $105-110$.

Harlapur, S. I., Kulkarni, M. S., Wali, M. C. \& Kulkarni, S. (2007) Evaluation of plant extracts, bio-agents and fungicides against Exserohilum turcicum (Pass.) Leonard and Suggs. causing Turcicum leaf blight of maize. Karnataka Journal of Agriculture Science 20(3), 541 - 544.

IITA. (1993) Crops Improvement Division/ Tuber root Improvement Program Archival Reports (1989-1993). Part III yam. Ibadan, Nigeria. $20-85$.

Ikotun, T. (1989) Diseases of yam tubers. International Journal Tropical Plant Disease 7, 1-21.

IMI. (1995) Regional Training Course on Fungal Identification. University of Zimbabwe, Zimbabwe. $33-78$.

Kalimuthu, C. P., Murugan, K. \& Hwang, J.-S. (2013) Green synthesis of silver nanoparticles using Cadaba indica lam leaf extract and its larvicidal and pupicidal activity against Anopheles stephensi and Culex quinquefasciatus. Journal of Entomological Acarological Research 45(11).

Noon, R. A. (1978) Storage and market disease of yam. Tropical Science 20, 177 - 188.

Ogundana, S. K., Naqvi, S. H. Z. \& Ekundayo J. A. (1970) Fungi associated with soft rot of yam (Dioscorea spp.) in storage in Nigeria. Transactions of British Mycological Society 54(3), $485-451$.

Okigbo, R. N. (2004) A review of biological control methods for post-harvest yams (Dioscorea spp.) in storage in south eastern Nigeria. KMITL Science Journal 4(1), 207 - 215.

Okigbo, R. N. \& Ikediugwu, F. E. O. (2000) Studies on biological control of post-harvest rot of yam (Dioscorea spp.) with Trichoderma viride. Journal of Phytopathology 148, 351 -355 .

Okigbo, R. N. \& Ogbonnaya, U. O. (2006). Antifungal effects of two tropical plant leaf extracts on postharvest yam rot. African Journal of Biotechnology 5(9), 727 - 731 .

Oluwole, O. B., Awororin, S. O., Henshaw, F., Elemo, G. N. \& Ebuehi, O. A. T. (2013) Assessment of microbial changes and nutritional qualities of extruded white yam (Dioscorea rotundata) and Bambara groundnut (Vigna subterranean) blends. Food and Nutrition Sciences 4, $100-107$.

Ooi, P. A. C. \& Shepard, B. M. (1994) Predators and parasitoids of rice insect pests. In E.A. Heinrichs, ed. Biology and Management of Rice Insects. Wiley, New Delhi, India, 585 - 612.

Saetae, D. \& Suntornsuk, W. (2010) Antifungal activities of ethanolic extract from Jatropha curcas seed cake. Journal of Microbiology and Biotechnology 20, 319 - 320 .

Sowley, E. N. K., Kankam, F. \& Afari, D. (2013) Evaluation of neem (Azadirachta indica) seed as potential control agents of yam (Dioscorea rotundata Poir.) tuber rot fungi. Archives of Phytopathology and Plant Protection, DOI.10.1080/03235408.2013.785659.

SRID. (2011) Ghana Agriculture. Ministry of Food and Agriculture, Statistics, Research and Information Directorate (SRID, 2011). 